\title{
ミクロスフェアを用いるイムノアッセイ TOPICS
}

臨床検查分野において，高感度・高 選択性分析法としてラジオイムノアッ セイ（RIA）が広く用いられているが， ラジオアイソトープの安全性・廃棄な どが問題になっている，最近これに代 わる高感度イムノアッセイ (IA) とし て高分子ミクロスフェアを用いた LA $^{1)}$, LPIA ${ }^{2)}$, PAMAIA ${ }^{3)}$ などが開 発された.これらの原理は, 抗体をコ ーティング（感作）したラテックス粒 子に抗原を反応させ, 生じた凝集の度 合を透過光変化, 粒度分布分析により 数值化するもので，ミクロスフェアを

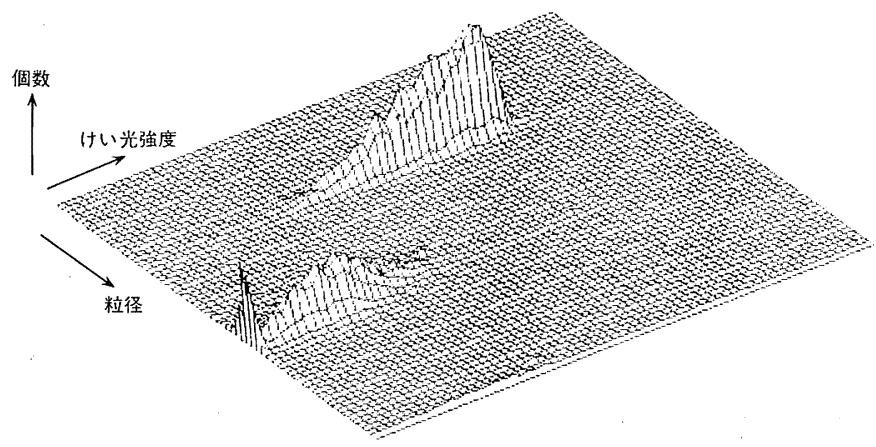

AFP $(15 \mu \mathrm{m}) 100 \mathrm{ng} \cdot \mathrm{m} l^{-1}$, CEA $(20 \mu \mathrm{m}) 1.56 \mathrm{ng} \cdot \mathrm{m} l^{-1}$

図 高分子ミクロスフェア法を用いた $\alpha$-フェトプロテイン (AFP) および癌胎児性抗原 (CEA) の同時検出

一種のプローブ・センサーとして用いた分析法として 位置付けられる。

われわれも高分子ミクロスフェアを用いた IA と， 当社のもつフローサイトメトリー (FCM) 技術を結び つけた新しい臨床検査システムの開発を行なっている が，このほど高感度同時複数項目測定に成功したの で, その結果を紹介したい. FCM についての詳細や 解説は成書 ${ }^{4)}$ に讓るが，血球（粒子）一つ一つの大き さ, けい光活性などを瞬時に分析し，その結果を 2 次 元，3次元的に表示するものと理解していただきた い.

さてわれわれは; 前述の LA などと同様にラテック ス粒子の凝集状態を FCM で分析する方法 (a) と，高 分子ミクロスフェアを固相として用いたけい光 IA (b) の 2 種について検討したが，今回は（b）について詳 しく紹介する．基本原理は，抗体を感作した粒子に測 定対象である抗原を作用させ，さらにけい光標識した 別の抗体を反応させた後, 粒子上に付着したけい光活 性を FCM で分析するというものである。この際, 数 種の均一粒径をもつ粒子を使用し，特定の粒径の粒子 とある特定対象抗原が一対一に反応するようにそれぞ れの粒子に別々の抗体を感作しておけば，同一の反応 系で数項目の同時測定ができるわけである。この複数 項目同時測定の発想は, FCM 技術の延長線上にある ものだが， $5 \sim 20 \mu \mathrm{m}$ 範囲の均一粒径をもつ単分散ビ 一ズの調整が可能になったことで，本技術的基盤が確 立した。また，本法は粒子ごとのけい光活性を測定し ているので, 粒子同士の凝集は絶対許されないわけ で，このため 5〜20 $\mu \mathrm{m}$ といった大粒径ビーズを使用 したり，感作抗体としてモノクローナル抗体を利用す

るなどのさまざまな工夫が施されている。

次に問題になるのは測定対象である. 血液凝固異常 の診断，炎症の診断など目的に応じて同時測定項目の 組み合わせはいろいろ考えられるが，われわれは特に 腫劰マーカーに注目し試験を行なった。今や死亡原因 の第 1 位が癌であるわけだが, いわゆる特効薬がない ため, 早期発見が最も有効な手段といわれている。近 ごろ腫場マーカーのコンビネーションアッセイが盛ん に研究され, 早期発見への有用性が示されている が5), われわれはその代表格である AFP（ $\alpha$-フェト プロテイン)・CEA（癌胎児性抗原）について同時測 定を試みた。図にその分析結果を立体表示で示した。 用いた粒子は $15 \mu \mathrm{m}$ (AFP) と $20 \mu \mathrm{m}$ (CEA) の 2 種 類で, 各々のビーズが独立した挙動を示しているのが わかる。な报, 感度は $\mathrm{ng} \cdot \mathrm{m} l^{-1}$ オーダーを達成して おり，十分に満足のいくものといえよう.

以上のように, 本法は RIA に匹敵する高感度・高選 択性分析法であり，しかも複数項目の同時測定が可能 であるという特長をもっており, 臨床検査における省 力化に大きく寄与するものと期待される.

\section{文献}

1) 坪田宜之: 医用電子と生体工学, 22, 267 (1984)

2) 筒井總明ら : 検查と技術, 12, 581 (1984)

3）竹中清悟ら : JJCLA, 11 (3), 226 (1986)

4）フローサイトメトリーハンドブック, 天神美夫ら編, サ イエンスフォーラム (1984)

5）石田 充ら：医学と薬学, 13, 1581 (1985)

水越 達也 Tatsuya Mizukoshi（昭和電工（株）生 化学研究所 - 主務, 専門 $=$ 生化学) 